\title{
Unilateral nasal obstruction on a background of sarcoidosis: an unusual diagnosis
}

\author{
Elaine Campbell 다, ${ }^{1}$ Oliver McLaren ${ }^{2}$
}

${ }^{1}$ ENT, Royal Cornwall Hospitals NHS Trust, Truro, UK

${ }^{2}$ ENT, South Devon NHS Foundation Trust, Truro, UK

\section{Correspondence to} Dr Elaine Campbell; elaine.campbell13@nhs.net

Accepted 3 September 2020

\section{DESCRIPTION}

This 79-year-old woman with sarcoidosis presented to the ENT (ear, nose and throat) outpatient service with increasing unilateral right-sided facial swelling and nasal obstruction, as shown in figure 1. Four years previously she had been treated for unilateral sinus disease on the right, and biopsies taken at that time showed inflammatory polypoid tissue only.

On examination in the clinic in May 2019, she was noted to have significant soft tissue swelling over her right maxillary sinus and a very congested right nasal cavity. An MRI scan was arranged at this time to establish the source of the swelling. The scan was performed in August 2019. Before this could be reported the patient was seen as an urgent case by the oral and maxillofacial surgery department following a referral from the patient's dentist. At this appointment in August 2019 the patient reported significant worsening of her right-sided facial swelling. The MRI showed a mass that had breached the superior, lateral and anterior maxillary sinus walls. Biopsies were taken from the right lateral nasal cavity under local anaesthetic in the clinic environment. The presumption was that this rapidly growing mass represented either a sinonasal or haematological malignancy or sarcoidosis. The biopsy results showed high grade B cell nonHodgkin's lymphoma.

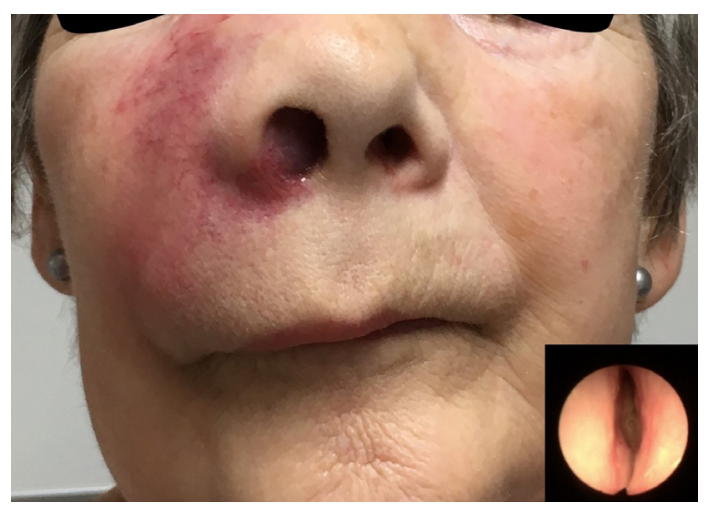

Figure 1 External swelling over the right maxilla. Inset: flexible nasendoscopy showing a mass in the right nasal cavity.

\section{Learning points}

- All unilateral nasal symptoms should be considered neoplastic until proven otherwise.

- Local anaesthetic biopsy is often well tolerated and provides rapid diagnosis.

- High-grade lymphoma responds well to high-dose steroids providing rapid relief of symptoms.

A referral was made to haematologists for management of lymphoma. Symptomatic relief was achieved with high-dose oral steroids.

This patient presented with a number of red flags for sinonasal malignancy. ${ }^{1}$ These included unilateral nasal obstruction, objective facial swelling and loose teeth on the affected side. The history of benign unilateral disease on the affected side may have clouded the clinical picture and raised the threshold for considering cancer. The history of dental problems was therefore considered to be the cause rather than the sequelae of a rapidly growing facial swelling.

\section{Twitter Oliver McLaren @boomclaren}

Contributors EC and OML contributed equally and wholly to the planning, conduct and reporting of the work described in this article. EC and OML gave substantial contributions to the conception of the work and the interpretation of data. EC drafted the work and OML revised it critically for important intellectual content. EC and OML gave final approval of the version published. EC and OML agree to be accountable for all aspects of the work in ensuring that questions related to the accuracy or integrity of any part of the work are appropriately investigated and resolved.

Funding The authors have not declared a specific grant for this research from any funding agency in the public, commercial or not-for-profit sectors.

Competing interests None declared.

Patient consent for publication Obtained.

Provenance and peer review Not commissioned; externally peer reviewed.

ORCID iD

Elaine Campbell http://orcid.org/0000-0002-7355-3955

\section{REFERENCE}

1 Slinger CA, McGarry GW. Nose and sinus tumours: red flags and referral. Br J Gen Pract 2018;68:247-8. 
Copyright 2020 BMJ Publishing Group. All rights reserved. For permission to reuse any of this content visit https://www.bmj.com/company/products-services/rights-and-licensing/permissions/

BMJ Case Report Fellows may re-use this article for personal use and teaching without any further permission.

Become a Fellow of BMJ Case Reports today and you can:

- Submit as many cases as you like

Enjoy fast sympathetic peer review and rapid publication of accepted articles

Access all the published articles

Re-use any of the published material for personal use and teaching without further permission

Customer Service

If you have any further queries about your subscription, please contact our customer services team on +44 (0) 2071111105 or via email at support@bmj.com.

Visit casereports.bmj.com for more articles like this and to become a Fellow 